\title{
ВАСКУЛОЕНДОТЕЛІАЛЬНИЙ ФАКТОР РОСТУ А ТА ПОЛІМОРФІЗМ G634С ГЕНА ВЕФР-А У ХВОРИХ ІНФАРКТОМ МІОКАРДА В ГОСТРИЙ ТА ВІДДАЛЕНИЙ ПЕРІОДИ
}

Копиця М. П., д. мед. н.

Кутя I. М., к. мед. н.

Родіонова Ю. В.

Україна, Харків, ДУ «Національний інститут терапї ім. Л.Т. Малої НАМН Украӥни»

DOI: https://doi.org/10.31435/rsglobal_ws/30082018/6061

\section{ARTICLE INFO}

Received: 04 July 2018

Accepted: 22 August 2018

Published: 30 August 2018

\section{KEYWORDS}

Vascular endothelial growth factor

A (VEGF-A),

acute myocardial infarction

ST-elevation STEMI,

VEGF-A gene polymorphism

(G634C),

left ventricle remodeling.

\begin{abstract}
Vascular endothelial growth factor A (VEGF-A) promotes the survival of endothelial cells during acute myocardial infarction, accelerates the development of collateral blood supply to ischemic myocardium, and affects the size diminishing of the necrotic lesion area. The synthesis of the VEGFA in response to standard stimuli is different between people that is genetically determined. The aim was to study the association of polymorphous variants of the VEGF-A gene (G634C) with the dynamics of structural and functional parameters of left ventricle in patients with acute ST elevation myocardial infarction (STEMI) during a 6-month period.

A significantly higher VEGF-A concentration was determined in the carriers of the GG genotype compared to the GC genotype $(p=0.047)$ in the acute period. It has been established that the genotype GC in patients with acute myocardial infarction ST-elevation (STEMI) is associated with more pronounced changes in the left ventricular geometry during the acute period. The GC genotype is associated with a better blood pressure control and a decrease in the left ventricle mass after 6 months' observation.
\end{abstract}

Citation: Копиця М. П., Кутя І. М., Родіонова Ю. В. (2018) Vaskuloendotelialnyi Faktor Rostu a ta Polimorfizm G634c Hena Vefr-A u Khvorykh Infarktom Miokarda v Hostryi ta Viddalenyi Periody. World Science. 8(36), Vol.2. doi: 0.31435/rsglobal_ws/30082018/6061

Copyright: () 2018 Копиця М. П., Кутя І. М., Родіонова Ю. В. This is an open-access article distributed under the terms of the Creative Commons Attribution License (CC BY). The use, distribution or reproduction in other forums is permitted, provided the original author(s) or licensor are credited and that the original publication in this journal is cited, in accordance with accepted academic practice. No use, distribution or reproduction is permitted which does not comply with these terms.

Вступ. Одним 3 важливих напрямків дослідження в кардіології $є$ вивчення ролі ангіогенезу в розвитку та прогресуванні серцево-судинних захворювань. Гострий інфаркт міокарда (ГІМ) являється одним з основних та грізних проявів захворювання системи кровообігу та вносить вагомий внесок у рівень смертності в усьому світі. В літературі накопичені дані про суттєві зміни в системі артеріо- та ангіогенезу при гострій ішемії, некротичному ураженні міокарда, проте значення цих змін дотепер залишається не до кінця зрозумілим.

Васкулоендотеліальний фактор росту-А (ВЕФР-А) - специфічний цитокін, що регулює процеси ангіо- та артеріогенезу при гострому інфаркті міокарда (ГІМ). Було показано, що різні типи клітин, в тому числі і кардіоміоцити $[9,20]$ здатні синтезувати даний біомаркер у відповідь на ішемію тканин [5, 6]. ВЕФР-А сприяє виживанню ендотеліальних клітин, підвищує проникливість стінки судин, регулює та прискорює розвиток колатерального кровообігу ішемізованого міокарда. ВЕФР-А впливає на підвищення щільності капілярної мережі, сприяє зменшенню розміру інфаркту міокарда в моделях на тваринах [2]. 
Та синтез ВЕФР-А у відповідь на співставні стимули відрізняється між людьми, так в популяції зустрічаються як стабільно низько продукуючі, так і високо продукуючі фенотипи при незмінній структурі синтезованого білка, що є генетично обумовлено [10]. Ген ВЕФР-А розташований на $6 \mathrm{p} 21.3$ хромосомі, має вісім екзонів, відділених сімома ітронами. Виділено близько 20 поліморфізмів, найбільше в промоторі 5'-нетранслюємій області (UTR) та 3'-UTR Було встановлено, що поліморфізм G634С гена ВЕФР-A (rs 2010963) є функціональним, тобто може впливати на рівень та швидкість секреції біомаркера [17].

На сьогоднішній день немає досліджень, котрі б вивчали вплив поліморфізму гена BЕФР-A (G634C) на синтез кодую чого ним білка у хворих на ГІМ з підйомом сегменту ST (ГIMпST), та асоціацію поліморфних варіантів зі зміною геометрії лівого шлуночку (ЛШ).

Метою нашої роботи стало вивчення асоціації поліморфних варіантів гена ВЕФР-А (G634C) 3 факторами серцево-судинного ризику, ускладненнями та динамікою структурнофункціональних параметрів міокарда ЛШ у хворих на гострий інфаркт міокарда 3 підйомом сегмента ST протягом 6-місячного періоду.

Матеріали і методи. До дослідження було залучено 91 пацієнта з ГIMпST, 70 (76,9\%) чоловіків та $21(23,1 \%)$ жінок, у середньому віці $(59,21 . \pm 8,92)$ років. Пацієнти були госпіталізовані у 2016-2017 pр. у відділення інтенсивної терапії ДУ «Національний інститут терапії імені Л.Т. Малої НАMН України» протягом перших трьох діб ГІМпST після стентування інфаркт-залежної коронарної артерії, котре проводили в Інституті загальної та невідкладної хірургії ім. В.Т. Зайцева та КЗОЗ «Обласна клінічна лікарня - Центр екстреної медичної допомоги та медицини катастроф». Групу контролю склали 12 практично здорових осіб, співставних за віком та статтю, які не мали скарг і будь-яких клінічно значущих відхилень з боку серцево-судинної системи.

Діагноз ГIMпST встановлювали відповідно до рекомендацій Європейського товариства кардіологів з діагностики та лікування хворих на ГIMпST (2017p.) 「4] та Наказу MO3 України №455 від 02.07.2014p "Про затвердження та впровадження медико-технологічних документів зі стандартизації медичної допомоги при гострому коронарному синдромі з елевацією сегмента ST". Дослідження проводили згідно положенням Гельсінської декларації, протокол дослідження узгоджено 3 комісією $з$ питань етики та деонтології ДУ «Національний інститут терапії імені Л.Т. Малої НАМН України» (протокол № 6 від 30.05.2017 p). Спостереження за хворими здійснювали протягом 6 місяців. Для повторного обстеження звернулось 57 пацієнтів. На госпітальному етапі помер 1 хворий, протягом 6 місяців спостереження - 2 хворих.

Всі обстежені отримували медикаментозну терапію відповідно до діючих рекомендацій: еноксапарин в лікувальній дозі 0.1 мг/кг ваги 2 раза на день, ацетилсаліцилова кислота 100 мг один раз на день, клопідогрель 75 мг один раз на день або тикагрелор 90 мг двічи, розувастатин 40 мг або аторвастатин 40-80 мг 1 раз на день, $\beta$-адреноблокатори, інгібітори АПФ. Розподіл пацієнтів згідно тактики реваскуляризації виглядав наступним чином: 57 - було проведено первинне черезшкірне коронарне втручання (ЧКВ) у вигляді стентування інфаркт-залежної коронарної артерії, 22 - тромболітична терапія з наступним ЧКВ, 6 - тромболітична терапія фібринспецифічним препаратом металізе (tenecteplase)), 6 пацієнтам не було проведено реваскуляризацію через відсутність технічних можливостей.

Ультразвукове дослідження пацієнтів проводили на 3-5 день госпіталізації та через 6 місяців спостереження на апараті Medison Sono Ace X6 (Корея), оцінювали кінцеводіастолічний (КДО) та кінцево-систолічний (КСО) об'єм ЛШ, кінцево-систолічний (КСД) та кінцево-діастолічний (КДД) діаметри ЛШ, масу міокарда ЛШ (ММЛШ), фракцію викиду (ФВ) ЛШ за Сімпсоном, діаметр лівого передсердя (ДЛП), діастолічну дисфункцію ЛШ максимальну швидкість раннього діастолічного наповнення $\mathrm{E}$ (м/с), максимальну швидкість передсердного діастолічного наповнення А (м/с), їх співвідношення E/A.

Для визначення толерантності до фізичного навантаження всім хворим проводився тест з 6-ти хвилинною ходьбою (Т6ХХ).

Дослідження алельного поліморфізму G634С гена ВЕФР-A (rs 2010963) проводили методом полімеразної ланцюгової реакції (ПЛР) в реальному часі з використанням наборів реактивів виробництва "СИНТОЛ" (РФ).

Рівень ВЕФР-А визначали імуноферментним методом 3 використанням набору реактивів IBLINTERNATIONAL GMBH, (Німеччина). Генетичні та імуно-біохімічні дослідження проводили у лабораторії імуно-біохімічних і молекулярно-генетичних досліджень ДУ «Національний інститут терапії ім. Л.Т. Малої НАМНУ». Кров для визначення ВЕФР-А в сироватці забирали на 5-7 день ГІМпSТ та через 6 місяців від події. Рівень ВЕФР-А в основній групі склав 160,33 [83,82 - 299,62] пг/мл., в контрольній - 112,30 [75,45-164,65] пг/мл, що мало 
достовірні відмінності $(\mathrm{P}=0,05)$. Артеріальну гіпертензію було діагностовано, якщо систолічний артеріальний тиск пацієнта склав $>140$ мм рт.ст., та/або діастолічний артеріальний тиск - >90 мм рт.ст. згідно до рекомендацій Європейської спілки кардіологів з діагностики та лікування артеріальної гіпертензії, 2013.

Статистичну обробку отриманих даних проведено за допомогою пакета програм Statistica 8.0 (Stat Soft Inc, CША), Microsoft Office Excel 2003. Дані представлені у вигляді медіани (Me), значеннями верхнього (UQ) та нижнього (LQ) квартилей вибірки, а також у вигляді середнього \pm стандартна похибка середнього $(\mathrm{M} \pm \sigma)$. Для оцінки міжгрупових відмінності застосовували U - крітерій Манна Уітні, $\chi^{2}$. Для всіх видів аналізу відмінності вважали статистично значущими при $\mathrm{p}<0,05$.

Результати та їх обговорення. Розподіл алелей і генотипів за поліморфним маркером G634C гена ВЕФР-A (rs 2010963) у хворих на ГІМпST відповідав закону Харді-Вайнберга. Спостерігалась наступна частота алелей: $\mathrm{G}-76 \%$ та C - 24\%, генотипів GG, GC - 52\% та 48\%. Гомозиготи за генотипом CC не виявили, тому подальший аналіз проводився у двох групах - y носіїв GG (n=48) та GC-генотипу (n=43).

Таблиця 1. Клінічна характеристика пацієнтів обох груп залежно від генотипів поліморфних варіантів G634C гена ВЕФР-А (rs 2010963)

\begin{tabular}{|c|c|c|c|}
\hline Показник & $\begin{array}{c}\mathrm{GG} \\
\mathrm{N}=48(52,7 \%)\end{array}$ & $\begin{array}{c}\mathrm{GC} \\
\mathrm{N}=43(47,3 \%) \\
\end{array}$ & $\chi^{2}, p$ \\
\hline Вік, років & $59,08 \pm 8,55$ & $59,35 \pm 9,42$ & 0,886 \\
\hline Стать ч/ж - n (\%) & $\begin{array}{c}37 / 11 \\
(77,1 \% / 22,9 \% \\
\end{array}$ & $\begin{array}{c}33 / 10 \\
(76,7 \% / 23,3 \%)\end{array}$ & $\begin{array}{c}0,04 \\
p=0,833\end{array}$ \\
\hline Артеріальна гіпертензія в анамнезі-n (\%) & $43(89,6 \%)$ & $35(81,4 \%)$ & $0,66 \mathrm{p}=0,415$ \\
\hline Цукровий діабет 2 типу-n (\%) & $13(27,1 \%)$ & $12(27,9 \%)$ & $0,01 \mathrm{p}=0,930$ \\
\hline Паління-n (\%) & $20(41,7 \%)$ & $17(39,5 \%)$ & $0,04 \mathrm{p}=0,836$ \\
\hline Обтяжена спадковість-n (\%) & $33(68,8 \%)$ & $26(60,5 \%)$ & $0,68 \mathrm{p}=0,409$ \\
\hline IM до 55 років, n (\%) & $1(2,1 \%)$ & $1(2,3 \%)$ & $0,41 \mathrm{p}=0,524$ \\
\hline $\mathrm{IMT} \geq 25 \kappa \mathrm{\kappa} / \mathrm{M}^{2}, \mathrm{n}(\%)$ & $42(87,5 \%)$ & $33(76,7 \%)$ & $1,14 \mathrm{p}=0,285$ \\
\hline Стабільна стенокардія в анамнезі, n (\%) & $15(31,3 \%)$ & $20(46,5 \%)$ & $2,23 \mathrm{p}=0,135$ \\
\hline Нестабільна стенокардія до IM, n (\%) & $16(33,3 \%)$ & $20(46,5 \%)$ & $1,65 \mathrm{p}=0,199$ \\
\hline IM в анамнезі, n (\%) & $7(14,6 \%)$ & $9(20,9 \%)$ & $0,27 \mathrm{p}=0,604$ \\
\hline \multicolumn{4}{|l|}{ Ускладнення IM в гострий період } \\
\hline ФК СН по Killip I-II, n (\%) & $40(83,3 \%)$ & $40(93,0 \%)$ & \multirow{2}{*}{$1,20 \mathrm{p}=0,274$} \\
\hline ФК СН по Killip III-IV, n (\%) & $8(16,7 \%)$ & $3(7,0 \%)$ & \\
\hline
\end{tabular}

При проведенні порівняльного аналізу в групах хворих на ГIMпST статистично значущих відмінностей для факторів серцево-судинного ризику та частоти ускладнень не було виявлено.

Таблиця 2. Клініко-біохімічна характеристика пацієнтів обох груп залежно від генотипів поліморфних варіантів G634C гена ВЕФР-A (rs 2010963) в гострий період та через 6 місяців $(\mathrm{M} \pm \sigma)$

\begin{tabular}{|l|c|c|c|c|}
\hline \multirow{2}{*}{ Показник } & \multicolumn{2}{|c|}{$\begin{array}{c}\text { GG } \\
\mathrm{N}=48(52,7 \%)\end{array}$} & $\begin{array}{c}\text { GC } \\
\mathrm{N}=43(47,3 \%)\end{array}$ & M-U, p \\
\hline \multirow{3}{*}{3 Х, ммоль/л } & 1 & $5,14 \pm 1,49$ & $4,93 \pm 1,19$ & 0,799 \\
\cline { 2 - 5 } & 2 & $3,98 \pm 1,10$ & $4,38 \pm 1,19$ & 0,194 \\
\cline { 2 - 5 } & $\mathrm{p}$ & 0,0003 & 0,032 & \\
\hline \multirow{3}{*}{ ХСЛПНЩ, ммоль/л } & 1 & $3,11 \pm 1,30$ & $2,96 \pm 1,00$ & 0,897 \\
\cline { 2 - 5 } & 2 & $2,25 \pm 0,90$ & $2,64 \pm 1,12$ & 0,179 \\
\hline \multirow{3}{*}{ ХСЛПВЩ, ммоль/л } & $\mathrm{p}$ & 0,002 & 0,104 & 0,678 \\
\cline { 2 - 5 } & 1 & $1,19 \pm 0,27$ & $1,18 \pm 0,21$ & 0,862 \\
\cline { 2 - 5 } & 2 & $1,04 \pm 0,25$ & $1,05 \pm 0,24$ & 0,354 \\
\hline \multirow{3}{*}{ ТГ, ммоль/л } & 1 & 0,011 & 0,035 & 0,471 \\
\cline { 2 - 5 } & 2 & $1,86 \pm 0,93$ & $1,72 \pm 0,34$ & \\
\cline { 2 - 5 } & $\mathrm{p}$ & $1,60 \pm 0,70$ & $1,46 \pm 0,75$ & 0,942 \\
\hline
\end{tabular}


Продолжение таблицы 1

\begin{tabular}{|l|c|c|c|c|}
\hline $\begin{array}{c}\text { ШКФ (Кокрофт-Голт), } \\
\text { мл/мин/1,73м }\end{array}$ & 1 & $\begin{array}{c}71,50 \\
{[60,50-89,50]}\end{array}$ & $\begin{array}{c}72,00 \\
{[59,00-91,00]}\end{array}$ & 0,970 \\
\hline КФК-МВ, ммоль/л & 1 & $\begin{array}{c}129,20 \\
{[44,90-319,10]}\end{array}$ & $\begin{array}{c}81,80 \\
{[44,90-275,80]}\end{array}$ & 0,448 \\
\hline \multirow{2}{*}{ Тропонін, нг/мл } & 1 & $\begin{array}{c}16,75 \\
{[5,41-115,00]}\end{array}$ & $\begin{array}{c}23,70 \\
{[6,34-75,50]}\end{array}$ & 0,408 \\
\hline \multirow{3}{*}{ ВЕФР-А, пг/мл } & 1 & $\begin{array}{c}194,10 \\
{[115,02-398,86]}\end{array}$ & $\begin{array}{c}148,44 \\
{[68,84-221,28]}\end{array}$ & 0,047 \\
\cline { 2 - 5 } & 2 & $\begin{array}{c}300,58 \\
{[154,50-459,92]}\end{array}$ & $\begin{array}{c}444,18 \\
{[236,42-685,58]}\end{array}$ & 0,220 \\
\cline { 2 - 5 } & $\mathrm{p}$ & 0,246 & 0,003 & \\
\hline
\end{tabular}

Примітки: 1 - дані обстеження у період первинної госпіталізації, 2 - дані через 6 місяців спостереження.

При повторному обстеженні було визначено зменшення показників ліпідного обміну, але при порівнянні двох груп хворих статистично значущих відмінностей виявлено не було, як в гострому періоді хвороби так і через півроку. Також не спостерігалось достовірних відмінностей в показниках карідіоспецифічних ферментів, таких як тропонін, креатинфосфокіназа (КФК), швидкість клубочкової фільтрації (табл. 2).

При оцінюванні показників рівня ВЕФР-А були визначені достовірно більш високі концентрації цього цитокіну в гострий період захворювання у носіїв генотипу GG 194,10 [115,02-398,86] пг/мл в порівнянні з власниками GC генотипу 148,44 [68,84-221,28] пг/мл, $(\mathrm{p}=0,047)$ (табл. 2). В той час як через 6 місяців відзначається достовірне збільшення ВЕФР-А в $\begin{array}{lllllll}\text { групі GC поліморфного варіанту } \mathrm{G634C} \text { гена } 3 & 148,44\end{array}$ $[68,84-221,28]$ пг/мл до 444,18 [236,42-685,58] пг/мл (p=0,003) (табл. 2). Підвищення біомаркеру спостерігалося і у носіїв групи GG, але воно було менш значимим.

В літературних джерелах думки науковців розійшлися, ряд публікацій свідчать, що носійство генотипу GG асоціюється з підвищеною концентрацією ВЕФР-А в сироватці крові пацієнтів [17], інші вказують на те, що алель С (генотипи GC, CC) є запорукою більш високих показників біомаркера у хворих на ХCH [15]. В дослідженні проведеному на популяції здорових людей, різниці між носіями поліморфних варіантів гена ВЕФР-А (rs 2010963) виявлено не було [4].

Отримані нами результати можуть вказувати на те, що носії генотипу GG більш швидко реагують на виникнення гострої ішемії, про що свідчить достовірно вища концентрація ВЕФРА в гострий період розвитку інфаркту міокарда в порівнянні з носіями GC генотипу. Через 6 місяців нами було визначено достовірне підвищення біомаркера в групі GC, а міжгрупові розбіжності за рівнем ВЕФР-А втратили достовірність.

Таблиця 3. Клініко-інструментальна характеристика обстежених хворих залежно від генотипів поліморфних варіантів G634С гена ВЕФР-A (rs 2010963) в гострий період IM та через 6 місяців.

\begin{tabular}{|c|c|c|c|c|}
\hline \multicolumn{2}{|c|}{ Показник } & $\begin{array}{c}\text { GG } \\
\mathrm{N}=48(52,7 \%)\end{array}$ & $\begin{array}{c}\mathrm{GC} \\
\mathrm{N}=43(47,3 \%)\end{array}$ & $\mathrm{M}-\mathrm{U}, \chi^{2}, \mathrm{p}$ \\
\hline \multicolumn{2}{|c|}{1} & 2 & 3 & 4 \\
\hline \multirow{3}{*}{ САТ $\geq 140$ мм рт.ст. } & 1 & $25(52,1 \%)$ & $16(37,2 \%)$ & $2,03 \mathrm{p}=0,154$ \\
\cline { 2 - 5 } & 2 & $18(37,5 \%)$ & $7(16,3 \%)$ & $4,12 \mathrm{p}=0,043$ \\
\cline { 2 - 5 } & $\mathrm{p}$ & 0,151 & 0,028 & \\
\hline \multirow{3}{*}{ ДАТ $\geq 90$ мм рт.ст. } & 1 & $12(12,5 \%)$ & $15(30,2 \%)$ & $4,32 \mathrm{p}=0,038$ \\
\cline { 2 - 5 } & 2 & $18(37,5 \%)$ & $6(14,0 \%)$ & $5,32 \mathrm{p}=0,021$ \\
\cline { 2 - 5 } & $\mathrm{p}$ & 0,187 & 0,045 & \\
\hline \multirow{3}{*}{ КДО ЛШ, мл } & 1 & $139,22 \pm 36,16$ & $154,73 \pm 38,01$ & $\mathrm{p}=0,049$ \\
\cline { 2 - 5 } & 2 & $142,73 \pm 34,42$ & $149,04 \pm 33,60$ & $\mathrm{p}=0,497$ \\
\hline \multirow{3}{*}{ КСО ЛШ, мл } & $\mathrm{P}$ & 0,779 & 0,667 & \\
& 1 & $62,03 \pm 21,85$ & $71,68 \pm 23,45$ & $\mathrm{P}=0,045$ \\
\cline { 2 - 5 } & 2 & $66,50 \pm 20,83$ & $71,69 \pm 26,55$ & $\mathrm{p}=0,421$ \\
\hline & $\mathrm{P}$ & 0,509 & 0,845 & \\
\hline
\end{tabular}


Продолжение таблицы 2

\begin{tabular}{|c|c|c|c|c|}
\hline \multicolumn{2}{|l|}{1} & 2 & 3 & 4 \\
\hline \multirow{3}{*}{ КДД ЛШ, см } & 1 & $5,37 \pm 0,63$ & $5,68 \pm 0,74$ & $\mathrm{p}=0,034$ \\
\hline & 2 & $5,33 \pm 0,61$ & $5,44 \pm 0,67$ & $p=0,508$ \\
\hline & $\mathrm{P}$ & 0,897 & 0,815 & \\
\hline \multirow{3}{*}{ КСД ЛШ, см } & 1 & $3,61 \pm 0,60$ & $3,92 \pm 0,78$ & $\mathrm{p}=0,035$ \\
\hline & 2 & $3,85 \pm 0,54$ & $4,04 \pm 0,53$ & $\mathrm{p}=0,272$ \\
\hline & $\mathrm{P}$ & 0,870 & 0,358 & \\
\hline \multirow{3}{*}{ ДЛП, см } & 1 & $4,08 \pm 0,48$ & $4,16 \pm 0,54$ & \\
\hline & 2 & $4,16 \pm 0,54$ & $4,19 \pm, 53$ & $p=0,847$ \\
\hline & $\mathrm{P}$ & 0,475 & 0,541 & \\
\hline \multirow{3}{*}{$\Phi B, \%$} & 1 & $52,58 \pm 13,48$ & $52,98 \pm 9,58$ & $\mathrm{p}=0,544$ \\
\hline & 2 & $54,15 \pm 6,65$ & $51,84 \pm 11,19$ & $\mathrm{p}=0,331$ \\
\hline & $\mathrm{P}$ & 0,475 & 0,331 & \\
\hline \multirow{3}{*}{$\mathrm{E} / \mathrm{A}$} & 1 & $0,95 \pm 0,69$ & $1,00 \pm 0,38$ & $p=0,299$ \\
\hline & 2 & $1,18 \pm 0,50$ & $1,05 \pm 0,52$ & $p=0,379$ \\
\hline & $\mathrm{P}$ & 0,249 & 0,701 & \\
\hline \multirow{3}{*}{ ММЛШ, г } & 1 & $214,27 \pm 75,43$ & $249,97 \pm 87,68$ & $p=0,0397$ \\
\hline & 2 & $262,35 \pm 77,92$ & $213,96 \pm 53,03$ & $\mathrm{p}=0,011$ \\
\hline & $\mathrm{P}$ & 0,737 & 0,039 & \\
\hline T6XX, м & & $437,41 \pm 133,30$ & $448,22 \pm 139,17$ & 0,792 \\
\hline $\begin{array}{l}\text { Повторні } \\
\text { через } 6 \text { міс }\end{array}$ & події & $16(33,3 \%)$ & $22(51,1 \%)$ & $2,96 \mathrm{p}=0,085$ \\
\hline
\end{tabular}

При повторному обстеженні у пацієнтів - носіїв генотипу GC виявлено достовірне зниження CAT $(p=0,028)$ та ДАТ $(p=0,045)$, та в порівнянні з власниками GG генотипу $(p=0,043)$ $\mathrm{i}(\mathrm{p}=0,021)$ відповідно.

Порівнюючи ехокардіографічні показники в гострий період хвороби в групі GCгенотипу спостерігались достовірні розбіжності по КДО ЛШ (P=0,049), КСО ЛШ $(\mathrm{P}=0,045)$, КДР ЛШ $(\mathrm{P}=0,034)$, КСР ЛШ $(\mathrm{P}=0,035)$ та маси міокарда ЛШ $(\mathrm{P}=0,04)$. Однак, через 6 місяців після події достовірних відмінностей в розмірах порожнини ЛШ не виявлено. Необхідно

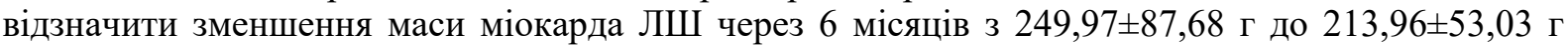
$(\mathrm{p}=0,039)$ у носіїв GC- генотипу. B той час в групі GG генотипу цей показник хоча i не

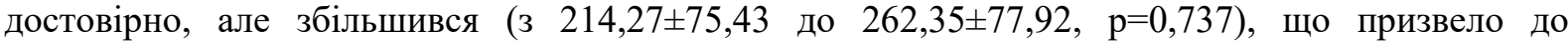
достовірних міжгрупових змін ( $\mathrm{p}=0,011)$ на користь хворих з $\mathrm{GC}$ генотипом. Підвищення рівня ВЕФР-А в поєднанні зі зменшенням ММЛШ, стабілізацією показників геометрії ЛШ (КДО, КСО) та ФВ через 6 міс в групі GC свідчить про позитивну роль біомаркера в патогенетичних механізмах післяінфарктного ремоделювання.

Нами не виявлено відмінностей між пацієнтами обох груп у величині показників тесту 3 6-ти хвилинної ходьбою та частоті повторних коронарних подій. Можливо це пов'язано 3 коротким терміном спостереження

Залишається не до кінця вивчені точні механізми підйому рівня ВЕФР-А в плазмі хворих IM в гострому та віддаленому періоді. Так, гіпоксія та ішемія є сильним стимулом продукції цитокіну [2]. Запалення є ще одним важливим фактором активації рівня ВЕФР в плазмі крові хворих на ГІМ [1]. Також, є ряд клініко-експериментальних досліджень, що свідчать про підвищення синтезу ВЕФР-А при механічному розтягненні кардіоміоцитів та збільшенню діастолічного тиску в ЛШ. Li J. Та співав. (1997), повідомляли, що індукція міокардіального розтягнення шляхом нагнітання в порожнині ЛШ тиску до 35 мм.рт.ст протягом 30 хвилин призвела майже до шестикратного збільшення продукції ВЄФР-А не тільки в порожнині ЛШ, а й системно [9]. Потім ці результати підтвердили Zheng W. та співавт (2001), було виявлено в експериментальних умовах, що концентрація ВЕФР-А збільшується в двічі після 1 часу розтягнення кардіоміоцитів. В цьому дослідженні було встановлено, що ВЕФР здатен збільшити щільність капілярної сітки на 23\% [20]. Згодом Leychenko А. та співавтори (2011) в експериментальному дослідженні виявили, що при циклічному механічному розтягненні кардіоміоцитів, імітуючи гіпертрофічні реакції, відбувається троєкратне підвищення секреції ВЕФР-А в порівнянні з контролем без розтягнення [8]. Хоча роль гіпоксії та ішемії в підвищенні концентрації ВСФВ-А добре відома, дані дослідження показують, що 
збільшення діастоличного тиску в ЛШ та слідом за цим розмірів камер серця забезпечують механічні стимули та призводять до адаптаційної активації процесів ангіогенезу.

Shimokawahara Н. та співавт. (2014 г.) також вивчали вплив рівня ВЕФР на розміри ЛШ після перенесеного ГІМ. Прийшли до висновку, що чім вищі показники рівня ВЕФР в гострій фазі захворювання, тим менше змінюються розміри ЛШ в хронічний період (через 6 місяців спостереження) хвороби [12].

Вивчення генетичного поліморфізму гена ВЕФР-А $\epsilon$ актуальною проблемою на сьогоднішній день, так як досліджуваний нами гаплотип G634C являється функціональним та впливає на секрецію біомаркера. Наші дані, які ми отримали через 6 місяців після перенесеного ГIM, співпадають з рядом досліджень, де показано що алель C (генотипи GC/CC) асоціюється 3 підвищенною концентрацією цитокіна в сиворотці крові при хронічній серцевій недостатності [18], IXC [17] та АГ [7]. Проте, в літературних джерелах немає досліджень де б вивчали асоціацію поліморфних варіантів гена ВЕФР-А з структурною перебудовою міокарду в гострий період хвороби. Ми спостерігали достовірно вищі показники рівня досліджуваного біомаркера в групі GG в гострий період (на 5-7 день) розвитку інфаркту міокарда. Це може вказувати на те, що при гострій ішемії тканин носії генотипу GG більш швидко реагують на провокуючі стимули в результаті чого концентрація біомаркеру зростає. Разом 3 тим, в цій групі не спостерігалось значних змін в геометрії ЛШ. Та протягом 6-місячного періоду, власники поліморфного генотипу GC мають достовірно вищу концентрацію ВЕФР-А в сиворотці крові. Також, Oliveira-Paula G. (2015 р.) повідомляють що поліморфні варіанти гена ВЕФР-А можуть впливати на антигіпертинзивну відповідь при лікуванні інгібіторами ангіотензинперетворюючого ферменту (ІАПФ) [11]. Показано, що ІАПФ, в свою чергу, сприяють збільшенню концентрації ВЕФР-А [3, 5, 13]. Сукупність даних факторів в поєднанні 3 збільшенням розмірів порожнини ЛШ яку ми спостерігали в гострий період захворювання, імовірно, вплинули на суттєве підвищення цитокіна в даній групі хворих у віддаленому періоді. Таким чином, активується процес ангіогенезу та покращення функції ендотелію судин, що позитивно впливає на рівень АТ, сприяє зменшенню маси міокарда ЛШ у віддалений період.

\section{Висновки.}

1. Визначено достовірно вищу концентрацію ВЕФР-А у носіїв генотипу GG в порівнянні з власниками GC генотипу $(\mathrm{p}=0,047)$ в гострий період ГIMпST.

2. Встановлено, що носійство генотипу GC у хворих на ГIMпST асоціюється з більш вираженими змінами геометрії ЛШ в гострий період,

3. Генотип GC асоціюється 3 кращим контролем АГ та зменшенням маси міокарда ЛШ через 6 місяців спостереження.

\section{ЛIТЕРАТУРА}

1. Ebrahimian TG, Tamarat R, Clergue M, Duriez M, Levy BI, Silvestre JS (2005) Dual effect of angiotensinconverting enzyme inhibition on angiogenesis in type 1 diabetic mice. Arterioscler Thromb Vasc Biol 25(1):65-70

2. Ferroni P, Della-Morte D, Palmirotta R, Rundek T, Guadagni F, Roselli M (2012) Angiogenesis and hypertension: the dual role of anti-hypertensive and anti-angiogenic therapies. Curr Vasc Pharmacol 10(4):479-493

3. Hagikura K, Fukuda N, Yokoyama S, Yuxin L, Kusumi Y, Matsumoto T, et al. Low invasive angiogenic therapy for myocardial infarction by retrograde transplantation of mononuclear cells expressing the VEGF gene. Int J ardiol 2010.-№. - p. 142:56- 64.

4. Heba H. Al-Habboubi, Mai S. Sater, Ahmad W. Almawi, Ghada M. Al-Khateeb, Wassim Y. Almawi. Contribution of VEGF polymorphisms to variation in VEGF serum levels in a healthy population// Eur. Cytokine Netw. 2011.- Vol. 22 n॰3, p. 154-8

5. Hervas, A. et al. Intracoronary Infusion of Thioflavin-S to Study Microvascular Obstruction in a Model of Myocardial Infarction. Rev Esp Cardiol. - 2015. № 68.- p. 928-934.

6. Hojo Y, Ikeda U, Zhu Y, Okada M, Ueno S, Arakawa H, Fujikawa H, Katsuki T, Shimada K. Expression of vascular endothelial growth factor in patients with acute myocardial infarction. J Am Coll Cardiol. - 2000.№ 35.-p. 968-73.

7. $\quad$ Lacchini R., Luizon M. R., Gasparini S., Ferreira-Sae M.S, Schreiber R., Nadruz W., Tanus-Santos J. E. Effect of Genetic Polymorphisms of Vascular Endothelial Growth Factor on Left Ventricular Hypertrophy in Patients with Systemic Hypertension. Am J Cardiol 2014; 113:491e496 http://dx.doi.org/10.1016/j.amjcard.2013.10.034 
8. Leychenko A., Konorev E., Jijiwa M., Matter M. Stretch-Induced Hypertrophy Activates NFkB-Mediated VEGF Secretion in Adult Cardiomyocytes. PLoS ONE. - December 13,2011.- № 6. https://doi.org/10.1371/journal.pone.0029055

9. 52.Li J., Hampton T., Morgan J P, Simons M. Stretch-induced VEGF expression in the heart. J Clin Invest. 1997 Jul 1; 100(1): 18-24. doi: 10.1172/JCI119510.

10. Li P, Kondo T, Numaguchi Y, Kobayashi K, Aoki M, Inoue N, Okumura K, Murohara T (2008) Role of bradykinin, nitric oxide, and angiotensin II type 2 receptor in imidapril-induced angiogene- sis. Hypertension 51(2):252-258

11. Oliveira-Paula G., Lacchini R, Fontana V, Silva PS, Biagi C, Tanus-Santos JE. Polymorphisms in VEGFA gene affect the antihypertensive responses to enalapril. Eur J Clin Pharmacol. 2015 Aug;71(8):949-57. doi: 10.1007/s00228-015-1872-5. Epub 2015 May 24. doi:10.1007/s00228-015-1872-5

12. Shimokawahara H., Jougasaki H., Setoguchi M. et al. Relationship between vascular endothelial growth factor and left ventricular dimension in patients with acute myocardial infarction// J Cardiol. - 2014 № 5. P. 360-365. DOI:10.1016/j.jjcc.2014.02.017

13. Silvestre JS, Kamsu-Kom N, Clergue M, Duriez M, Levy BI (2002) Very-low-dose combination of the angiotensin-converting enzyme inhibitor perindopril and the diuretic indapamide induces an early and sustained increase in neovascularization in rat ischemic legs. J Pharmacol Exp Ther 303(3):1038-1043

14. Soeki T., Tamura Y., Shinohara H., Tanaka H., Bando K., Fukuda N., Serial Changes in Serum VEGF and HGF in Patients with Acute Myocardial Infarction. Cardiology 2000;93:168-174. DOI:10.1159/000007022

15. Тепляков А.Т., Березикова Е.Н., Шилов С.Н. Сердечная недостаточность. Клинико-генетические аспекты ишемического ремоделирования и апоптоза миокарда в развитии сердечной недостаточности. Томск: STT, 2015. — 400 с. — ISBN 978-5-93629-542-3

16. Toblli JE, Cao G, DeRosa G, Di Gennaro F, Forcada P (2004) Angiotensin-converting enzyme inhibition and angiogenesis in myocardium of obese Zucker rats. Am J Hypertens 17(2):172-180

17. Watson C. J., Webb N. J., Bottomley M. J., Brenchley P. E. C. Identification of polymorphisms within the vascular endothelial growth factor (VEGF) gene: correlation with variation in VEGF protein production. Cytokine. - 2000.-№ 12(8). - p.1232-1235. doi:10.1006/cyto.2000.0692.

18. Wojakowski W, Maslankiewicz K, Ochala A, Wyderka R, Zuk-Popiolek I, Flak Z, Mroz I, Tendera M. The pro- and anti-inflammatory markers in patients with acute myocardial infarction and chronic stable angina.Int J Mol Med. 2004 Aug;14(2):317-22.

19. Yazawa H, Miyachi M, Furukawa M, Takahashi K, Takatsu M, Tsuboi K, Ohtake M, Murase T, Hattori T, Kato Y, Murohara T, Nagata K (2011) Angiotensin-converting enzyme inhibition pro- motes coronary angiogenesis in the failing heart of Dahl salt- sensitive hypertensive rats. J Card Fail 17(12):1041-1050

20. Zheng W, Seftor EA, Meininger CJ, Hendrix MJ, Tomanek RJ. Mechanisms of coronary angiogenesis in response to stretch: role of VEGF and TGF-beta. Am J Physiol Heart Circ Physiol. 2001 Feb;280(2):H909-17. 